\title{
ANALISIS PENGELOLAAN BENDA SITAAN DAN BARANG RAMPASAN NEGARA DI DALAMRUMAH PENYIMPANAN BENDA SITAAN DAN BARANG RAMPASAN NEGARA (RUPBASAN)
}

\author{
LOLLONG MANTING ${ }^{1)}$, PANTJA BAMBANG SUDARWANTO ${ }^{2)}$ \\ ${ }^{1,2}$ Dosen Pendidikan Ekonomi Universitas Pamulang \\ dosen01943@unpam.ac.id ${ }^{1}$,dosen01827@unpam.ac.id ${ }^{2}$
}

\begin{abstract}
ABSTRAK
Rumah Penyimpanan Benda Sitaan dan Barang Rampasan Negara (Rupbasan) adalah sebuah institusi negara yang berada di bawah Kementerian Hukum dan hak Asasi Manusia yang melakukan proses pemeliharaan, perawatan dan pengamanan terhadap semua benda sitaan dan barang rampasan dengan tujuan untuk menjaga dan memastikan kualitas dan mutu dari benda sitaan dan barang rampasan tersebut tidak berkurang. Manajemen atau pengelolaan terhadap benda sitaan dan barang rampasan negara yang berada di dalam Rupbasan sangat ditentukan oleh adanya sumber daya manusia yang memadai, baik dari segi kuantitas terlebih lagi kualitas, adanya sarana dan prasarana yang cukup sesuai dengan kebutuhan dasar Rupbasan, dan adanya anggaran yang cukup untuk mendukung semua kegiatan dalam proses pemeliharan sampai kepada pengeluaran basan dan baran tersebut. Hasil penelitian yang dilakukan menunjukkan bahwa keberadaan Rupbasan di Indonesia sangat minim, yang seharusnya berada di di seluruh kabupaten/kota yang jumlahnya kurang lebih 500 kabupaten/kota, namun pada kenyataannya Rupbasan yang ada hanya berjumlah 63 Rupbasan di seluruh Indonesia. Dari 63 Rupbasan ini hanya 27 unit yang status lahannya adalah milik sendiri. Termasuk tidak ada satupun Rupbasan yang memiliki gudang yang lengkap untuk menyimpan semua jenis benda sitaan dan barang rampasan.
\end{abstract}

Kata Kunci : pengelolaan, benda sitaan, barang rampasan, rupbasan

\section{PENDAHULUAN}

Rumah Penyimpanan Benda

Sitaan dan Barang Rampasan Negara yang selanjutnya disingkat Rupbasan adalah salah satu unit pelaksana teknis (UPT) yang berada dibawah Kementerian Hukum dan Hak Asasi Manusia, Republik Indonesia. Rupbasan adalah lembaga yang bertanggung jawab untuk melakukan pengelolaan terhadap semua benda sitaan dan barang rampasan negara sesuai dengan Pasal 44 Kitab UndangUndang Hukum Acara Pidana (KUHAP), yang menyatakan bahwa benda sitaan dan barang rampasan disimpan dalam Rumah Penyimpanan 
Benda Sitaan Negara dalam hal ini adalah Rupbasan.

Menurut Peraturan Pemerintah Nomor 27 Tahun 1983 Tentang Pelaksanaan Kitab Undang-Undang Hukum acara Pidana, Rupbasan adalah tempat untuk menyimpan benda yang sita oleh negara untuk keperluan proses pereadilan, sedangkan yang dimaksud dengan prose peradilan adalah proses pemeriksaan perkara pada tahapan tingkat penyidikan, pemeriksaan pada tingkat penuntutan dan pmeriksaan pada tingkat peradilan.

Disebutkan dalam Pasal 26 PP Nomor 27 tahun 1983, yang pada prinsipnya pengadaan Rupbasan sejalan dengan pengadaan Rutan yaitu di setiap ibu kota Kabupaten atau
Kotamadya dan bila mana dipandang perlu Menteri Kehakiman dapat mendirikan cabang Rupbasan. Kalau mengacu pada PP Nomor 27 tahun 1983, maka hal ini berarti bahwa secara ideal jumlah Rupbasan semestinya berbanding lurus dengan jumlah kabupaten/ kotamadya/ kota administratif yang ada di Indonesia setidaknya ada lebih dari 500 unit dari Sabang sampai Merauke.

Dalam

kenyataanya menunjukan bahwa keberadaan Rupbasan di Indonesia hanya terdapat di beberapa wilayah sebagaimana tergambar dalam Tabel 1.1 di bawah ini :

Tabel 1.1 Jumlah Rupbasan di Indonesia

\begin{tabular}{|c|c|c|c|}
\hline \multicolumn{2}{|r|}{ Rupbasan Kelas I } & \multicolumn{2}{|r|}{ Rupbasan Kelas II } \\
\hline No & Lokasi & No & Lokasi \\
\hline 1 & Banda aceh & 1 & Bangkinang \\
\hline 2 & Medan & 2 & Bengkalis \\
\hline 3 & Padang & 3 & Rengat \\
\hline 4 & Pekan baru & 4 & Tanjung pinang \\
\hline 5 & Jambi & 5 & Baturaja \\
\hline 6 & Palembang & 6 & Pangkal pinang \\
\hline 7 & Lampung & 7 & Metro \\
\hline 8 & Bengkulu & 8 & Kotabumi \\
\hline 9 & Jakarta barat & 9 & Arga makmur \\
\hline 10 & Jakarta selatan & 10 & Serang \\
\hline 11 & Jakarta timur & 11 & Indramayu \\
\hline 12 & Jakarta utara & 12 & Wonosari \\
\hline 13 & Jakarta pusat & 13 & Water \\
\hline 14 & Bandung & 14 & Bantul \\
\hline 15 & Cirebon & 15 & Wonogiri \\
\hline 16 & Yogyakarta & 16 & Cilacap \\
\hline
\end{tabular}




\begin{tabular}{|l|l|l|l|}
\hline 17 & Semarang & 17 & Purbalingga \\
\hline 18 & Surakarta & 18 & Purwokerto \\
\hline 19 & Pekalongan & 19 & Sragen \\
\hline 20 & Surabaya & 20 & Blitar \\
\hline 21 & Probolinggo & 21 & Jombang \\
\hline 22 & Pasuruan & 22 & Mojokerto \\
\hline 23 & Pontianak & 23 & Sanggau \\
\hline 24 & Singkawang & 24 & Sumbawa besar \\
\hline 25 & Palangkarata & 25 & Ternate \\
\hline 26 & Banjarmasin & 26 & Monokwari \\
\hline 27 & Samarindah & & \\
\hline 28 & Manado & & \\
\hline 29 & Gorontalo & & \\
\hline 30 & Palu & & \\
\hline 31 & Makassar & & \\
\hline 32 & Kendari & & \\
\hline 33 & Denpasar & & \\
\hline 34 & Mataram & & \\
\hline 35 & Kupang & & \\
\hline 36 & Ambon & & \\
\hline 37 & Jayapura & & \\
\hline
\end{tabular}

Sumber : Data diolah dari dari sistem data base pemasyaraktan tahun 2019

Tabel 1.1. di atas menunjukkan bahwa saat ini di Indonesia hanya terdapat 63 (enam puluh tiga) unit pelaksana teknis Rupbasan, yang terdiri dari Rupbasan Klas I sebanyak 37 unit dan Rupbasan Klas II sebanyak 26 unit.
Data yang menarik adalah status lahan di mana kantor Rupbasan itu berdiri, dari 63 Rupbasan di Indonesia hanya 27 unit yang status lahannya adalah milik sendiri, seperti tabel di bawah ini :

Tabel 1.2 Status Kepemilikan

\begin{tabular}{|l|r|l|l|l|c|c|}
\hline \multicolumn{7}{|c|}{ STATUS KEPEMILIKAN LAHAN RUPBASAN } \\
\hline Milik Sendiri & 27 & unit & & Hak pakai tanah negara & 1 & unit \\
\hline Hak pakai & 3 & unit & & Milik lapas & 5 & unit \\
\hline Milik kanwil & 8 & unit & & Ex bapas & 1 & unit \\
\hline Ex lp & 2 & unit & & Hak guna pakai lp & 1 & unit \\
\hline Ex rumah dinas & 2 & unit & & Ex gedung bhp & 2 & unit \\
\hline Hibah pemerintah & 1 & unit & & Ex gedung agraria & 1 & unit \\
\hline Ngontrak rumah & 1 & unit & & Milik rutan & 1 & unit \\
\hline Hibah hak pakai & 1 & unit & & Milik pemda & 1 & unit \\
\hline
\end{tabular}




\begin{tabular}{|l|r|l|l|l|l|l|}
\hline Numpang di rutan & 1 & unit & & Ex lp & 1 & unit \\
\hline Ngontrak & 1 & unit & & Aula kanwil & 1 & unit \\
\hline Ex puskesmas pemda & 1 & unit & & & \\
\hline
\end{tabular}

belum ada satupun Rupbasan yang memenuhi standar ideal sebagai suatu Rupbasan yang semestinya memiliki lima jenis gudang yang berbeda seperti gudang umum tertutup, gudang umum terbuka, gudang berharga, gudang berbahaya dan kandang untuk hewan dan tumbuhan serta sarana Rupbasan yang hanya memiliki 2 (dua), atau 3 (tiga) jenis gudang saja, bahkan ada kantor Rupbasan yang hanya tidak memiliki gudang, hal ini menjadi permasalahan didalam penempatan Basan dan Baran di dalam gudang Rupbasan. Seperti yang terlihat pada Tabel 1.3 di bawah ini : utilitas dan prasarana lingkungan.

Tabel 1.3 Fasilitas Gudang

\begin{tabular}{|l|r|l|}
\hline \multicolumn{1}{|c|}{ KEPEMILIKAN GUDANG } & \multicolumn{2}{c|}{ JUMLAH } \\
\hline Jumlah rupbasan yang memiliki 5 gudang & - & Unit \\
\hline Jumlah rupbasan yang memiliki 4 gudang & 19 & Unit \\
\hline Jumlah rupbasan yang memiliki 3 gudang & 21 & Unit \\
\hline Jumlah rupbasan yang memiliki 2 gudang & 17 & Unit \\
\hline Jumlah rupbasan yang memiliki 1 gudang & 4 & Unit \\
\hline Jumlah rupbasan yang tidak memiliki gudang & 2 & Unit \\
\hline JUMLAH & $\mathbf{6 3}$ & Unit \\
\hline
\end{tabular}

Melihat realitas bahwa sebagaimana diamanatkan dalam keberadaan Rupbasan masih sangat Undang-undang Nomor 8 Tahun 1981 kurang dari segi jumlahnya, status lahan yang sebagian besar belum milik tentang KUHAP dan Peraturan Pemerintah Nomor 27 tahun 1983 sendiri, dan jumlah gudang yang masih sangat jauh dari memadai dan standar yang ada maka Implementasi terhadap ketentuan yang mengatur tentang Rupbasan dalam rangka pengelolaan semua benda dan barang yang disita oleh negara dan akan digunakan dalam proses peradilan

Tentang Pelaksanaan KUHAP sesungguhnya belum dapat dilaksanakan secara maksimal, hal ini disebabkan karena masih minimnya Rupbasan yang memadai sebagai rumah penyimpanan benda sitaan negara, padahal dalam mekanisme proses penegakan hukum dinyatakan 
secara tegas dalam UU bahwa benda sitaan disimpan dalam Rupbasan.

Selain kondisi keterbatasan jumlah kantor Rupbasan dan keterbatasan status, masalah krusial lainnya adalah aspek manajemen atau pengelolaan benda sitaan dan barang rampasan yang berada dalam Rupbasan, aspek pemenuhan terhadapa kualitas dan kuatintas sumber daya manusia (petugas), pemenuhana terhadap sarana dan prasananya, termasuk bagaimana pemenuhan dan ketersediaan terhadap anggaran demi terlaksanya tugas dan fungsi petugas.

Peraturan Pemerintah Nomor 24 tahun 2005 tentang Standar Akuntansi Pemerintah mendefiniskan bahwa yang dimaksud dengan asset adalah sumber daya ekonomi yang dikuasai dan atau dimiliki oleh pemerintah sebagai akibat dari peristiwa masa lalu dan dari mana manfaat ekonomi dan/atau sosial di masa depan diharapkan dapat diperoleh, baik oleh pemerintah maupun masyarakat, serta dapat diukur dalam satuan uang, termasuk sumber daya non keuangan yang diperlukan untuk penyediaan jasa bagi masyarakat umum dan sumber-sumber daya yang dipelihara karena alasan sejarah dan budaya."

\section{Undang-Undang Nomor 1} tahun 2004 tentang Perbendaharaan Negara, mendefinisikan barang milik negara yang diklasifikasikan sebagai asset atau kekayaan negara yaitu "semua barang yang dibeli atau diperoleh atas beban anggaran pendapatan dan belanja negara atau berasal dari perolehan lain yang sah".

Peraturan Pemerintah Nomor 38 tahun 2008 tentang Pengelolaan barang Negara menyebutkan bahwa salah satu sumber perolehan yang sah dan dimilikinoleh negara adalah barang yang diperoleh berdasarkan putusan pengadilan dan telah memiliki kekuatan hukum yang mengikat, olehnya itu jika mengacu pada regulasi tersebut di atas maka yang dimaksud dengan asset pidana adalah "Aset Tindak Pidana adalah semua benda bergerak atau tidak bergerak, baik berwujud atau tidak berwujud dan mempunyai nilai ekonomis yang diperoleh atau diduga berasal dari tindak pidana".

Sedangkan yang dimaksud dengan benda sitaan adalah benda yang disita oleh penyidik, penuntut umum atau pejabat yang karena jabatannya memiliki kewenangan untuk melakukan penyitaan terhadap barang tersebut sebagau barang bukti dalam proses peradilan. Adapun pengertian barang rampasan adalah semua benda sitaan yang berdasarkan keputusan pengadilan dan telah memilikikekuatan hukum tetap dinyatakan dirampas oleh negara.

\section{METODE PENELITIAN}

Penelitian ini akan mendeskripsikan realitas pengelolaan Basan Baran yang dilakukan di 
Rupbasan. Jenis penelitian yang digunakan adalah deskriptif kualitatif dengan studi literatur dan hasil observasi atau pengamatan langsung.

\section{HASIL DAN PEMBAHASAN Pengelolaan Penerimaan Basan dan Baran}

Berdasarkan penelitian yang dilakukan diketahui bahwa pelaksanaan tugas dan dan fungsi penerimaan yang dilaksanakan oleh petugas penerima Basan sudah dilakukan sesuai dengan ketentuan yang ada, seperti meneliti berkas berkas penerimaan dan kelengkapan administrasi lainnya, dalam hal melakukan penelitian dan penilaian Kepala Rupbasan membentuk tim untuk peneliti, tim ini terdiri dari pejabat yang membidangi administrasi sebagai Ketua, ahli peneliti yang membidangi objek Basan dan Baran, serta petugas administrasi peneliti. Adapun proses pendokumentasian, petugas melakukan pemotretan atau pengambilan gambar terhadap fisik Basan dan Baran untuk didokumentasikan.

Dalam proses penerimaan dan pelimpahan benda sitaan dan barang rampasan negara, dokumen dari institusi yang memiliki kewenangan secara yuridis banyak yang tidak lengkap disebabkan tidak diberitahukannya perkembangan proses pelimpahan perkara antar instansi sehingga perkembangan status hukum sulit diketahui, dan kemudian berdampak pada aktifitas pengadministrasian.

Terkait dengan sumber daya manusia, sampai saat ini petugas yang memiliki keahlian spesifik dalam melakukan penilaian terhadap Basan dan Baran belum memadai baik kuantitas maupun kualitas bahkan dapat dikatakan masih banyak Rupbasan belum memiliki sama sekali tenaga ahli peneliti dan penilai, karena ketiadaan SDM yang dimakasud maka Rupbasan hanya menempatkan petugas untuk melakukan penelitian dan penilaian secara umum.

Pemenuhan terhadap semua fasilitas pendukung sebagai penopang utama terlaksananya tugas pokok dan fungsi petugas secara optimal masih sangat minim. Sarana dan prasarana terutama gudang-gudang penyimpanan dan sarana pendukung pemeliharaan yang dapat menimbulkan berkurangnya nilai ekonomis Basan dan Baran karena rusak, pencurian, kebakaran dan lain-lain masih jauh dari memadai. Pemenuhan sarana dan prasarana yang cukup vital dan menjadi kebutuhan pada semua kantor Rupbasan sesuai standar seperti alat derek dan lain lain untuk memudahkan menarik kendaraan yang kondisi mesinnya tidak berfungsi seyogyanya harus segera dipenuhi, untuk melakukan pendokumentasian Basan Baran juga dibutuhkan kamera digital dengan spesifikasi tertentu termasuk kebutuhan yang mendesak, timbangan digital untuk barang berharga serta alat 
deteksi barang berharga merupakan kebutuhan penting lainnya yang mendesak untuk dipenuhi.

\section{Pendaftaran Basan dan Baran}

Dalam melakukan tugas dan fungsi pengregistrasian atau pendaftaran Basan, Rupbasan masih dihadapkan pada kendala yang sederhana namun sangat menganggu yaitu tidak memadainya sarana dan prasarana yang dibutuhkan seperti komputer dan printer. Adapun fasilitas website kalaupun tersedia masih sering offline. Dari sisi sumber daya manusia, kemampuan petugas dalam mengoperasikan komputer secara standar seperti microsoft word dan XL masih kurang memadai termasuk minimnya kemampuan dalam mengelola website. Kenyataan lain yang ditemukan pada beberapa Rupbasan adalah metode pencatatan masih dilakukan secara manual dan masih menggunakan buku lama.

\section{Pengklasifikasian dan Penempatan Basan Baran}

Petugas pengklasifikasian dan penempatan telah melakukan tugas dan fungsinya dengan cukup baik, dalam pengertian bahwa petugas telah melakukan pemilahan terhadap Basan dan Baran yang akan disimpan baik secara langsung maupun tidak langsung dan menentukan tempat yang sesuai dengan kondisi yang ada, namun hal ini tidak bisa berjalan dengan baik karena keterbatasan tempat atau gudang untuk menempatkan Basan dan Baran yang ada.

Ketentuan bahwa setiap kantor Rupbasan semestinya memiliki lima jenis gudang yang berbeda seperti gudang umum, gudang tertutup, gudang umum terbuka, gudang khusus berharga, gudang khusus berbahaya dan gudang untuk hewan dan tumbuhan sepertinya masih bersifat regulatif dan sangat jauh dari kenyataan yang ada.

Tidak sedikit Rupbasan yang hany memiliki 2 (dua) jenis gudang saja, bahkan ada kantor Rupbasan yang hanya memiliki 1 (satu) gudang. Fakta ini yang kemudian menjadi kendala utama dalam melakukan penempatan terhadap Basan dan Baran dalam Rupbasan dan sebagai konsekuensinya kegiatan pengklasifikasian yang dilanjutkan dengan penempatan tidak berjalan dengan baik sehingga kondisi Basan dan Baran banyak yang mengalami kerusakan atau berkurang mutu dan kualitasnya.

\section{Pemeliharaan Basan Baran}

Kegiatan pemeliharaan Basan dan Baran di Rupbasan bertujuan menjamin dan mempertahankan kualitas dan kuantitas Basan dan Baran selama disimpan di Rupbasan. Kegiatan pemeliharaan dapat dilaksanakan menggunakan metode Preventive Maintenance secara berkala sesuai waktu yang ditentukan. Tetapi untuk benda sitaan tertentu yang memerlukan pemeliharaan yang 
segera dapat dilaksanakan pemeliharaan secara darurat (emergency). Kegiatan pemeliharaan sudah berjalan sesuai dengan kemampuan yang ada dengan mekanisme yang disesuaikan dengan kondisi riil di lapangan, kondisi Basan dan Baran serta kemampuan petugas. Hal-hal standar yang dilakukan dalam konteks pemeliharaan, misalnya untuk kendaraan roda dua dan roda empat adalah memanaskan dan membersihkan serta memeriksa kondisi mesin. Dan untuk pemeliharaan terhadap Basan dan Baran yang lain dilakukan secara normatif.

\section{Pengamanan Basan Baran}

Secara umum diketahui bahwa tugas pengamanan adalah menyelenggarakan aktifitas keamanan dan keselamatan dari segala bentuk gangguan keamanan Basan dan Baran di Rupbasan. Sedangkan Fungsi pengamanan adalah melakukan pencegahan dan penanggulangan terhadap terjadinya berbagai gangguan keamanan. Petugas pengamanan dan sarana prasarana keamanan sangat terbatas, fakta di lapangan petugas hanya 10 (sepuluh) orang yang dibagi ke dalam 4 (empat) regu. Sarana dan prasana pengamanan juga masih jauh dari memadai.

\section{Pemutasian Basan dan Baran}

Pemutasian Basan adalah kegiatan pemindahan Basan secara administrasi berdasarkan status hukum sesuai tingkat pemeriksaan perkara, sedangkan Mutasi adalah kegiatan pemutasian Basan secara administrasi yang berkaitan dengan peralihan kewenangan yuridis Basan yang disertai dengan perubahan pencatatan pada buku register. Proses mutasi terhadap Basan dan Baran mengalami beberapa kendala terkait dengan pelimpahan perkaran dan informasi perkembangan status hukum, terutama terhadap Basan dan Baran yang sudah di atas 2 tahun. Tidak ada informasi yang pasti, di sisi lain surat koordinasi ataupun permintaan secara lisan bahkan dengan berkunjung langsung ke pihak-pihak instansi terkait sudah dilakukan namun tidak mendapatkan hasil yang diharapkan.

\section{Pengeluaran Basan Baran}

Pengeluaran adalah tindakan mengeluarkan Basan dan Baran dari Rupbasan. Pengeluara ini dilakukan baik sebelum adanya putusan pengadilan maupun setelah adanya putusan pengadilan berdasarkan penetapan hakim atau Putusan Pengadilan. Proses pemindahan Basan dan Baran dari dalam Rupbasan kepada pihak yang memiliki kewenangan penuh untuk melakukan pengambilan Basan dan Baran dilakukan sesuai dengan aturan yang ada. Kegiatan ini diawali dengan melakukan pemeriksaan atau pengecekan fisik dan kelengkapan berkas Basan dan Baran setelah itu dibuatkan berita acara yang diketahui dan ditandatangani oleh semua pihak. 


\section{KESIMPULAN}

Berdasarkan penelitian yang dilakukan, dapat dikemukakan kesimpulan sebagai berikut:

1. Manajemen atau pengelolaan yang dilakukan Rupbasan terhadap semua benda sitaan dan baramg rampasan bertujuan untuk menjaga, memastikan, menjamin keutuhan Basan dan Baran baik dari segi jenis, kadar, kualitas dan kuantitasnya.

2. Proses pengelolaan Basan dan Baran di mulai dari penerimaan, penelitian, penilaian, dan pengregistrasian Basan Baran, pengklasifikasian dan penempatan Basan Baran, pemeliharaan Basan Baran, pemutasian Basan Baran, pngeluaran dan penghapusan Basan Baran, penggunaan Benda sitaan untuk digunakan dalam proses peradilan, pengamanan dan penyelamatan Basan Baran.

3. Pelaksanaan tugas dan fungsi pengelolaan Basan Baran di Indonesia berdasarkan data yang ada dapat dikatakan masih sangat jauh dari ideal karena masih adanya kendala atau hambatan-hambatan yang sudah ada sekian puluh tahun bahkan masalah ini sudah muncul sejak awal berdirinya Rupbasan. Adapun hambatan yang mengemuka dalam pelaksanaan pengelolaan Basan dan Baran meliputi hambatan internal dan hambatan eksternal.
Hambatan internal adalah sebagai berikut :

a. Terbatasnya kualitas dan kuantitas petugas Rupbasan;

b. Minimnya pemenuhan terhadap sarana dan prasarana Rupbasan; Sarana dan prasarana yang begitu vital dalam proses penerimaan, penelitian, penilaian sampai kepada proses penempatan, pengamanan dan pemeliharan termasuk ketersedian geduang dan atau gudang sangat terbatas sehingga tidak memenuhi standar ideal.

c. Anggaran yang masih sangat minim untuk mendukung peningkatan kinerja Rupbasan

d. Kurangnya political will dan good will pemerintah untuk secara serius melakukan pembenahan Rupbasan

Adapun hambatan eksternal adalah:

a. Stigma yang berasal institusi penegak hukum lain seperti kepolisian, kejaksanan, dan Pengadilan yang menganggap bahwa Rupbasan belum mampu menyimpan/mengelola benda sitaan negara.

b. Kurangnya pemahaman aparat penegak hukum untuk menegakkan peraturan perundangan-undangan tentang Rupbasan. 
REFERENSI

Keputusan Direktur Jenderal

Pemasyarakatan Nomor PAS140.PK.02.01. (2015). Petunjuk

Pelaksanaan Pengelolaan Benda

Sitaan dan Barang Rampasan

Negara.

Peraturan Pemerintah Nomor 27

Tahun 1983 tentang Pelaksanaan

Kitab Undang-Undang Hukum

Acara Pidana.

Standar Identifikasi Basan Baran.

2015. Direktorat Jenderal

Pemasyarakatan, Kementerian

Hukum dan Hak Asasi Manusia,

Republik Indonesia

Standar Pemeliharaan Basan Baran.

(2015). Direktorat Jenderal

Pemasyarakatan, Kementerian

Hukum dan Hak Asasi Manusia,

Republik Indonesia

Santosa, Bima Priya dkk. (2010).

Lembaga Pengelola Aset Tindak

Pidana. Jakarta: Paramadina

Public Policy Institute.

Silalahi, Uber. (2012). Metode

Penelitian Sosil. Cetakan Ketiga.

Bandung: PT. Refika Aditama.

Tim Pengkajian Hukum. (2013).

Lembaga Penyitaan dan

Pengelolaan Barang Hasil

Kejahatan. Kementerian Hukum

dan Hak Asasi Manusia RI,

Jakarta: Badan Pembinaan Hukum

Nasional.

Undang-Undang Republik Indonesia

Nomor 8 Tahun 1981 tentang

Hukum Acara Pidana
Undang-Undang Nomor 12 tahun 1999 tentang Pemasyarakat. 